Publications of the Hudson's Bay Record Society, Vol. II

Edited by E. E. Rich, assisted by A. M. Johnson. (Copy-Book of Letters Outward \&c., Begins 29th Mry 1680, Ends 5 July 1687.) Edited by E. E. Rich, assisted by A. M. Johnson. Pp. xli+416+x. (London: Hudson's Bay Record Society, 1948.) n.p.

HIS large, beautifully produced book appears at first sight forbidding and dull ; but it is far from being either. It consists mainly of letters sent from the Hudson's Bay Company to its servants on the shores of the Bay. These letters deal with the everyday life of the servants, the prevention of trespass by interlopers, the founding of new settlements, and the quarrels with the French as to rights of the Company in North America. In all these matters there is much that is still of interest. There is a homely touch, in a letter to Governor Nixon : "We have sent you a qr. cask of choice Malaga Sack for your owne drinking, we have likewise sent a Cask of Noremberg Toyes for childrens play games to make an experiment how such things will take with the Indians". There is reproof: Mr. Mussenden is told "we hope we shall heare no more of such factions and disorders", and Governor Nixon that "you have carried your selfe with too much inhumanity and cruelty towards the Natives". A long section of the correspondence deals with the French menace, and the documents setting out the English title to Hudson Bay are of great interest.

Such details as these must be picked out by careful reading. But the whole of the correspondence is welded together in a brilliant introduction by Prof. E. G. R. Taylor. She reviews the state of cartographical knowledge in the period and shows how this was related to claims of the disputants. She shows how ignorance of the geography of the new lands both affected the actual settlements and mystified the directors of the Company in London. Sometimes she reads into the seventeenth century facts which are more relevant of our own times, as, for example, the different way in which Russians and East Europeans would have tackled the problems set to Englishmen. But this does not detract from a most enlightening introduction to this valuable work.

J. N. L. B.

Twilight in India

By Gervee Baronte. Pp. xix +382 . (New York: Philosophical Library, Inc., 1949.) 3.75 dollars.

THIS book is well named, for the author has a very dim view of India. In spite of a good deal of interesting and, on the whole, well-informed matter on south Indian castes, the whole book is coloured by an obvious determination to view everything Hindu in the darkest shadow, and all the less creditable aspects of Hinduism, particularly in regard to sex, are enlarged on at the expense of its merits.

There is obviously a good deal of exaggeration in many of the statements made, for the meriah sacrifice is written of - and that in 1949-as if it continued as a routine ceremonial. Several of the illustrations are borrowed without acknowledgment from Thurston; and, although misprints abound, the fact that "tumeric" is repeatedly used for "turmeric" suggests that possibly it is not the printer who is to blame for "foistered" instead of "foisted"-or perhaps "fostered".

The most valuable part of this volume is constituted by the twelve chapters (there are twenty-six in all) on castes ; but one can only use them with a certain dubious reserve engendered by doubts arising not only from the author's obviously biased approach, but also from suspicions that she has been wishfully credulous of the monstrous and the unpleasant, and from the perusal of statements which are manifestly, not in accordance with the facts: "Most of the I.C.S.," she tells us, "knew only the North, which, . . . is not India. . . . It is only in the Dravidian south that one meets real Hinduism." Both statements are misleading.

J. H. HuTtoN

Das Molekül und der Aufbau der Materie

Vorträge von W. Kossel, F. Fund, E. Justi, O. Kratky und P. A. Thiessen. Herausgegeben von K. W. Wagner. (Die Wissenschaft, Band 101.) Pp. vii +319 . (Braunschweig: Friedr. Vieweg und Sohn, 1949.) 18.80 D. marks.

7 HIS volume contains the text of lectures given in 1943-44, and hence in many aspects it cannot claim to give the present-day state of the subjects dealt with. These are heteropolar compounds and the growth of crystals by W. Kossel (occupying the first 119 pages), homopolar compounds and the quantum theory of valency by $F$. Hund, the calculation of specific heats of gases from spectrum data by E. Justi, macromolecules by O. Kratky (which has been revised), and colloids by P. A. Thiessen.

The last two are very short and elementary. The longer articles give a very good picture of the subjects at the time the lectures were given, and the book contains much of permanent value, the articles by Kossel and Hund being particularly noteworthy. The section by Justi does not include any recent work except his own publications and gives, in consequence, a rather misleading picture of the present position in this field.

Since most of the recent work on all the topics dealt with has been done outside Germany, it is doubtful whether this volume, interesting as it is, will add very much to the existing literature in its field.

\section{Normal Values in Clinical Medicine}

By Prof. F. William Sunderman and Dr. Frederick Boerner. Pp. xxx +835. (Philadelphia and London: W. B. Saunders Co., 1949.) 14 dollars; $70 s$.

DROF. SUNDERMAN and the late Dr. Boemer, in conjunction with several colleagues, mainly of the University of Pennsylvania, are to be congratulated on having brought together in the compass of one book so much valuable information concerning normal values in clinical medicine. This must make it a very useful reference book and one which should ease the burden of the busy clinician, while the number of collaborators each covering his own particular field must add to the reliability of the information.

Without a knowledge of 'normals', abnormals are not easily determined, the more so in clinical medicine where the range of normal may be wide. It is probable there are certain omissions-they are difficult to find-since should the reader wish to know the average number of 'chews' per test-meal, he will find a paragraph devoted to the subject. There is an up-to-date bibliography at the end of each chapter.

The last section, on "Miscellaneous Data", although not pertinent to normal values in clinical medicine, is usefully incorporated. The book should not only satisfy the requirements of the clinician but should also be of value to the student of advanced physiology as well as "the enquiring medical student". 